\title{
ZUSGS
}

science for a changing world

U.S. DEPARTMENT OF THE INTERIOR

U.S. GEOLOGICAL SURVEY

\section{Thickness and geometry of Cenozoic deposits in California Wash area, Nevada, based on gravity and seismic-reflection data}

by V.E. Langenheim ${ }^{1}$, J.J. Miller ${ }^{2}$, W.R. Page ${ }^{2}$, and J.A. Grow ${ }^{2}$

Open-File Report 01-393

2001

Prepared in cooperation with the National Park Service

This report is preliminary and has not been reviewed for conformity with U.S. Geological Survey editorial standards or with the North American Stratigraphic Code. Any use of trade, firm, or product names is for descriptive purposes only and does not imply endorsement by the U.S. Government.

U.S. DEPARTMENT OF THE INTERIOR

U.S. GEOLOGICAL SURVEY

${ }^{1}$ Menlo Park, California

${ }^{2}$ Denver, Colorado, Nevada 


\section{TABLE OF CONTENTS}

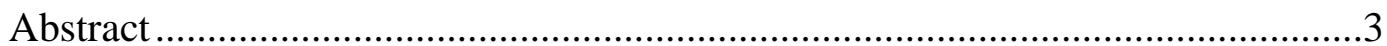

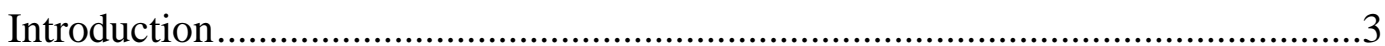

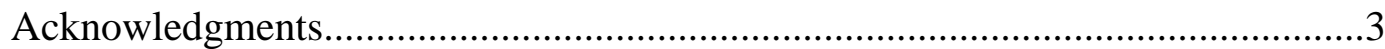

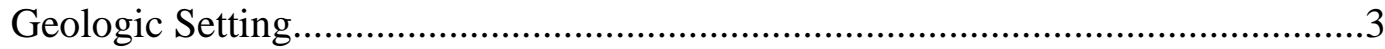

Drill Hole Data and Physical Properties ............................................................

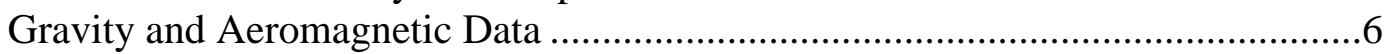

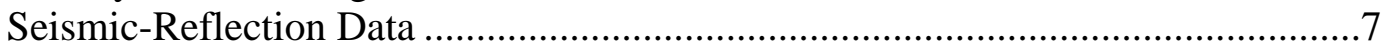

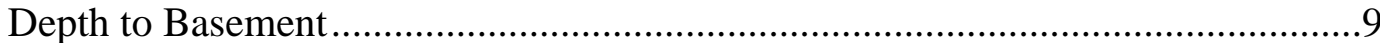

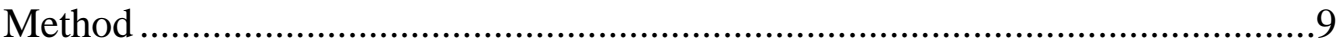

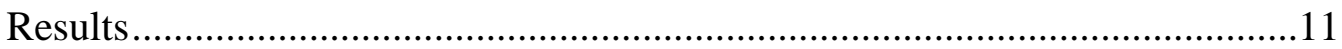

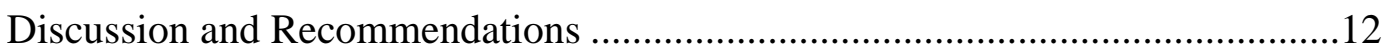

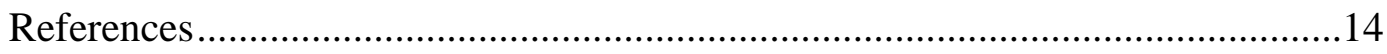

\section{TABLES}

Table 1. Sonic velocities and corresponding densities of Cenozoic deposits.........6

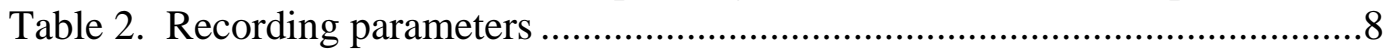

Table 3. Density-depth functions ....................................................................11

\section{FIGURES}

Figure 1. Topographic map of the region......................................................17

Figure 2. Geologic map of study area............................................................18

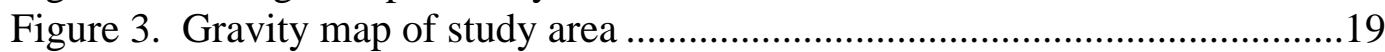

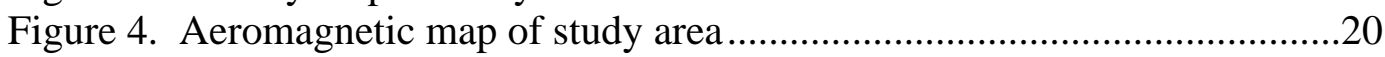

Figure 5. Seismic-reflection and potential-field data along LV-1 .......................21

Figure 6. Seismic-reflection and potential-field data along LV-1aext ..................22

Figure 7. Seismic-reflection and potential-field data along LV-3 ......................23

Figure 8. Schematic diagram of gravity separation method ...................................24

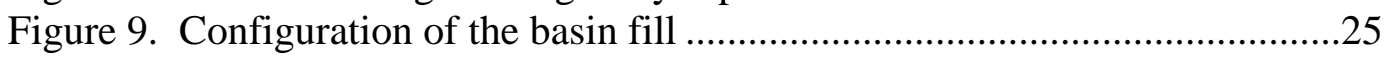

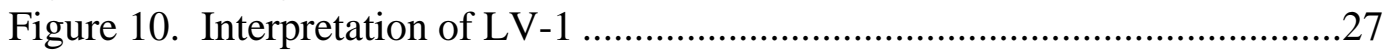




\begin{abstract}
Gravity and seismic-reflection data provide insights into the subsurface stratigraphy and structure of the California Wash area of southern Nevada. This area is part of the Lower Colorado flow system and stratigraphic and structural data are important inputs into developing the hydrogeologic framework. These data indicate that the basin beneath California Wash reaches depths of 2-3 km. The eastern margin of the basin coincides with a system of young (Quaternary and late Tertiary) faults, although both seismic and gravity data indicate that the major basin-bounding fault is $2-3 \mathrm{~km}$ west of the mapped young faults. Dry Lake Valley, the adjacent valley to the west, is characterized by thinner basin fill. The basin configuration beneath both California Wash and Dry Lake Valleys based on the inversion of gravity data is unconstrained because of the lack of gravity stations north of $36^{0} 30^{\prime}$. Broad aeromagnetic anomalies beneath pre-Cenozoic basement in the Muddy Mountains and Arrow Canyon Range reflect Precambrian basement at depths of $\sim 5 \mathrm{~km}$. These rocks are probably barriers to ground-water flow, except where fractured.
\end{abstract}

\title{
INTRODUCTION
}

At the request of the National Park Service, the U.S. Geological Survey conducted analysis of gravity and seismic-reflection data in support of hydrogeologic framework studies of the California Wash area, Nevada (Fig. 1). Gravity data were inverted for thickness of alluvial deposits using a method developed by Jachens and Moring (1990). The inversion was constrained by picks on the thickness of the Cenozoic deposits from three seismic-reflection profiles. Two different models were created to provide limits on the configuration of the ground-water basin and locate faults within the basin.

\section{ACKNOWLEDGEMENTS}

We wish to thank the National Park Service Water Resources Division (Fort Collins, CO) for supporting this work. We thank Sue Beard and Bob Bohannon (U.S. Geological Survey) for their thoughtful and thought-provoking reviews.

\section{GEOLOGIC SETTING}

The mountain ranges in the study area (box in Fig. 1) expose Paleozoic and Mesozoic sedimentary rocks (Fig. 2). These rocks are presumably underlain by Precambrian crystalline basement rocks, such as those exposed in the Virgin Mountains, 
approximately $50 \mathrm{~km}$ east of California Wash (Fig. 1). The Paleozoic sequence consists of mostly carbonate rocks, which form the major groundwater aquifers in southeast Nevada (Dettinger and others, 1995). Upper Proterozoic sedimentary rocks underlie the Paleozoic sequence in the Spring Mountains (west of Las Vegas) and Sheep Range but are probably absent in this area because these rocks are absent at Frenchman Mountain and in the Virgin Mountains (Longwell and others, 1965). No Proterozoic sedimentary rocks were found at the Virgin Mobil 1A drill hole east of the study area (Fig. 1; Bohannon and others, 1993). Mesozoic rocks, overlying the Paleozoic sequence, are predominantly clastic sedimentary rocks (Tschanz and Pampeyan, 1970; Longwell and others, 1965). In general, of the various bedrock units, only the Paleozoic carbonate units have potential for transmitting large quantities of water (Winograd and Thordarson, 1975; Dettinger and others, 1995). The rest of the pre-Cenozoic sequence is well-consolidated and impermeable and tends to act as a barrier to ground water movement.

The Paleozoic and Mesozoic rocks were affected by the Sevier orogeny, an episode of Cretaceous and early Tertiary (?) decollement thrusting. Cretaceous synorogenic rocks were eroded from emerging thrust highlands and deposited in front of the advancing thrust sheets. These deposits were cut by the oldest thrust faults (e.g., Willow Tank-Summit thrust faults) during Albian-Cenomanian time, but overlap the younger thrust faults (e.g., Muddy Mountain thrust; Bohannon, 1983). These thrust faults (and associated folds) are the dominant structures exposed in the ranges; for example, the Dry Lake thrust fault is the dominant structural feature of the Dry Lake Range and projects north beneath the alluvial deposits of Dry Lake valley (Fig. 2; Longwell and others, 1965). The northernmost exposure of the Dry Lake thrust fault is in the north central Arrow Canyon Range where it is interpreted to terminate into the Arrow Canyon anticline (Page, 1992; Page and Dixon, 1992).

During the Miocene, crustal extension led to development of basin and range topography in the study area. The basins are filled with Miocene to Quaternary sedimentary rocks and unconsolidated deposits. The Muddy Creek Formation is locally exposed within the California Wash basin and is inferred to underlie the younger alluvial deposits (Bohannon, 1984). The Muddy Creek Formation consists of nonmarine siltstone, sandstone, conglomerate, and some paleo-spring carbonate rocks. The Muddy 
Creek commonly contains gypsum, which is water-soluble, and introduces sulfates into the groundwater, causing very poor water quality. Below the Muddy Creek is the Horse Spring Formation, which is exposed south and east of the California Wash basin. The Horse Spring Formation is composed of Miocene nonmarine conglomerate, shale, sandstone, siltstone, limestone, evaporites, and volcanic rocks (Longwell and others, 1965; Bohannon, 1984). Both of these Cenozoic sedimentary packages reflect the latest tectonic episode of the region by exhibiting large changes in thickness across basinbounding normal faults according to seismic-reflection data in the Virgin River Valley, some $50 \mathrm{~km}$ to the northeast (Bohannon and others, 1993; Carpenter and Carpenter, 1994). The Muddy Creek Formation fills modern topographic depressions (such as the Virgin Valley); older Cenozoic rocks are commonly tectonically disrupted by normal and strike-slip faults.

These basin fill deposits can also be important local aquifers. Because of the large density contrast between the basin fill and the surrounding pre-Cenozoic rocks (in particular the Paleozoic carbonate sequence), gravity techniques are well suited for defining the subsurface shapes of basins and the geometries of faults that bound the basins.

\section{DRILL HOLE DATA AND PHYSICAL PROPERTIES}

The only well constraints in the study area are from two shallow water wells in Dry Lake Valley taken from a Nevada Department of Conservation \& Natural Resources Water Resources Reconnaissance Report (Rush, 1968) and two wells drilled by the U.S. Air Force as part of the Nevada-Utah MX missile-siting investigation in Coyote Springs Valley (Berger and others, 1988). A deep oil test drillhole ("Grace" on Fig. 2) does not provide information on the thickness of Cenozoic fill, but penetrates the Paleozoic sequence which is repeated (Cambrian over Pennsylvanian rocks) by the inferred projection of the Dry Lake thrust fault at a depth of $\sim 2.8 \mathrm{~km}$.

No direct measurements are available on the density of the Cenozoic sedimentary deposits of the basins along LV-1. Indirect information comes from sonic velocities measured in the Mobil Virgin River 1A well $40 \mathrm{~km}$ to the northeast (Fig. 1). Using the relationship of Gardner and others (1974) developed for sedimentary rocks, 


$$
\rho=0.23 \mathrm{v}^{0.25}
$$

we estimate the density, $\rho\left(\mathrm{g} / \mathrm{cm}^{3}\right)$, from the sonic velocity, $v(\mathrm{ft} / \mathrm{s})$. Sonic velocities measured on Cenozoic sedimentary rocks in the Mobil Virgin River 1A well are 2.1-3.0 $\mathrm{km} / \mathrm{s}(7,000-10,000 \mathrm{ft} / \mathrm{s})$ for the first second of two-way travel time (TWTT), increasing to $5.5 \mathrm{~km} / \mathrm{s}(18,000 \mathrm{ft} / \mathrm{s})$ at about 2 seconds TWTT (Bohannon and others, 1993).

We calculated interval velocities along seismic-reflection profile LV-1 (Fig. 1). It is difficult to assess the uncertainties in these interval velocities because of the lack of well $\log s$ and check shots. The error is probably $+/-10 \%$, but could be as high as $+/-$ $20 \%$. Velocities are poorly constrained beneath $2.0 \mathrm{~s}$ (approximately $3 \mathrm{~km}$ ). These velocities are generally higher than those measured in the Mobil Virgin River 1A well (Table 1).

\section{$\underline{\text { Table 1--Sonic velocities and calculated densities }}$}

(A) Mobil Virgin River 1A well from Bohannon and others (1993)

Depth Average

(in $\mathrm{km}) * \quad$ Velocity $(\mathrm{km} / \mathrm{s}) \quad$ Density $\left(\mathrm{g} / \mathrm{cm}^{3}\right)$

$0-0.5 \quad 2.1 \quad 2.11$

$\begin{array}{lll}0.5-1.3 & 2.3 & 2.15\end{array}$

$\begin{array}{lll}0.3-2.1 & 3.3 & 2.35\end{array}$

$\begin{array}{lll} & 2.1 & 4.1\end{array}$

(B) Interval velocities from our analysis along LV-1

\begin{tabular}{lll}
\hline $0-0.6$ & 2.1 & 2.10 \\
$0.6-1.2$ & 3.4 & 2.36 \\
$1.2-1.8$ & 4.2 & 2.49 \\
$>1.8 * *$ & 4.8 & 2.58
\end{tabular}

*based on average velocity

** poorly constrained

\section{GRAVITY AND MAGNETIC DATA}

Nearly 400 stations were used to create an isostatic gravity map of the region

(Kane and others, 1979; Langenheim and others, 1999; Phelps and others, 2000). Gravity stations are non-uniformly distributed in the area (fig. 2). Station spacing is on average 1 
station per $4 \mathrm{~km}^{2}$, though the station spacing can be as low as 1 station per $10 \mathrm{~km}^{2}$ in the mountainous regions and even within parts of the valleys north of $36^{\circ} 30^{\prime}$.

Gravity data were reduced using the Geodetic Reference System of 1967 (International Union of Geodesy and Geophysics, 1971) and referenced to the International Gravity Standardization Net 1971 gravity datum (Morelli, 1974, p. 18).

Gravity data were reduced to isostatic anomalies using a reduction density of $2.67 \mathrm{~g} / \mathrm{cm}^{3}$ and include earth-tide, instrument drift, free-air, Bouguer, latitude, curvature, and terrain corrections. An isostatic correction using a sea-level crustal thickness of $25 \mathrm{~km}$ (16 mi), a crustal density of $2.67 \mathrm{~g} / \mathrm{cm}^{3}$, and a mantle-crust density contrast of $0.40 \mathrm{~g} / \mathrm{cm}^{3}$ was applied to the gravity data to remove long-wavelength gravitational effect of isostatic compensation of the crust due to topographic loading. The resulting field is termed the isostatic gravity anomaly and reflects, to first order, density variations within the middle and upper crust (Fig. 3; Simpson and others, 1986). As expected, the valleys are characterized by gravity lows (associated with low-density Cenozoic fill) and the surrounding ranges are characterized by gravity highs.

Aeromagnetic data (fig. 4) consist of a regional survey (U.S. Geological Survey, 1983; Saltus and Ponce, 1988). The regional data were flown at $1000 \mathrm{ft}$ above ground along east-west flightlines spaced 1 mile apart. In the southern Basin and Range, the two important lithologies for producing aeromagnetic anomalies are Tertiary volcanic rocks and Precambrian crystalline basement. In our study area, neither of these lithologies are exposed. However, given the smooth character of the aeromagnetic anomalies, buried Precambrian crystalline basement (or Tertiary intrusions) is a likely source of the anomalies in Figure 4.

\section{SEISMIC-REFLECTION DATA}

The U.S. Geological Survey reprocessed $43 \mathrm{~km}$ of multi-channel seismicreflection data along three lines, LV-1, LV-1aext, and LV-3 (Fig. 1). The profiles were purchased from Seitel, Inc. with limited publication rights.

The lines were originally acquired by Pacific West Exploration Co., in the fall of 1978 and winter of 1979. Figures 5-7 show the depth sections of these seismic profiles with corresponding potential-field data. The U.S. Geological Survey bought limited 
publication rights of these seismic-reflection data for three reasons: (1) to obtain independent data on the thickness of Cenozoic fill as constraints for the gravity inversion, (2) to calculate the density of the basin fill from seismic velocities (see above section on drill holes and physical properties), and (3) to image the structure within the basin fill.

All three lines were recorded with the following common recording parameters: nominal subsurface coverage 24 fold, CDP interval of $110 \mathrm{ft}$. $(33.5 \mathrm{~m})$, record length of 6s. Recording parameters are listed in Table 2. Reflected energy was typically rich in frequencies between 8 to $60 \mathrm{~Hz}$ on lines LV-1 and LV-3. On line LV-1aext, the frequency range was necessarily limited to the $8-40 \mathrm{hz}$, frequency range of the Vibroseis sweep. The data were reprocessed using a crooked line geometry scheme (where necessary) and a processing flow which consisted of automatic gain control, 2-window spiking deconvolution, 2 passes of velocity analyses and 2 passes of surface consistent residual statics calculations. The data were migrated after stacking using a time- and space-varying velocity field, derived by smoothing the final stacking velocities. Typical near-surface interval velocities used for migration were $2.4 \mathrm{~km} / \mathrm{s}$ and velocities increased to approximately $6.0 \mathrm{~km} / \mathrm{s}$ at a two way travel time (TWTT) of $2.5 \mathrm{~s}$. The migrated data were then converted to depth using the same interval velocity field as that used for migration.

Table 2. Recording parameters

\begin{tabular}{|c|c|c|c|c|c|c|c|}
\hline Line & $\begin{array}{c}\text { No. of } \\
\text { Channels }\end{array}$ & $\begin{array}{c}\text { Source } \\
\text { Type }\end{array}$ & $\begin{array}{c}\text { Length/ } \\
\text { Depth }\end{array}$ & $\begin{array}{c}\text { Sample } \\
\text { Interval }\end{array}$ & $\begin{array}{c}\text { Max. Source- } \\
\text { Receiver } \\
\text { Offset }\end{array}$ & $\begin{array}{c}\text { Line } \\
\text { Length }\end{array}$ & Recorded \\
\hline LV-1 & 96 & $\begin{array}{c}\text { Primacord } \\
\text { (explosive) }\end{array}$ & $\begin{array}{c}67 \mathrm{~m} . / \\
76 \mathrm{~cm}\end{array}$ & $4 \mathrm{~ms}$ & $3,353 \mathrm{~m}$ & $14.14 \mathrm{~km}$ & $\begin{array}{c}\text { Sept. } \\
1978\end{array}$ \\
\hline LV- & 48 & $\begin{array}{c}\text { Vibroseis } \\
8-40 \mathrm{hz}\end{array}$ & $\begin{array}{c}18 \mathrm{~s} / \\
\text { Surface }\end{array}$ & $4 \mathrm{~ms}$ & $3,017 \mathrm{~m}$ & $7.81 \mathrm{~km}$ & $\begin{array}{c}\text { Feb. } \\
1979\end{array}$ \\
\hline LV-3 & 48 & $\begin{array}{c}\text { Primacord } \\
\text { (explosive) }\end{array}$ & $\begin{array}{c}67 \mathrm{~m} . / \\
76 \mathrm{~cm}\end{array}$ & $2 \mathrm{~ms}$ & $1,743 \mathrm{~m}$ & $12.56 \mathrm{~km}$ & $\begin{array}{c}\text { Oct. } \\
1978\end{array}$ \\
\hline
\end{tabular}

All three transects clearly show strong, coherent reflections indicative of basin fill in the upper 1-3 km. Along LV-1, we interpret the flat reflections between $\mathrm{km} 2$ and $\mathrm{km}$ 6 (horizontal distance) to be basin fill that unconformably overlies west-dipping Paleozoic rocks (Fig. 5). Outcrops of Bird Spring Formation in the northernmost Dry Lake Range interrupt reflections at $\mathrm{km} 8$ and separate the two basins. Another 
unconformity between flat reflections and east-dipping reflections occurs between $\mathrm{km} 10$ and 13. The basin fill reflections appear to terminate eastward at about $\mathrm{km} 21-22$ where we interpret the main basin margin fault. The fault position coincides with a pronounced gravity gradient of $\sim 15 \mathrm{mGal}$. A possible fault-plane reflection occurs at about $2 \mathrm{~km}$ depth at $\mathrm{km} 21$, suggesting a listric geometry to the basin-bounding fault.

Along LV-1aext, basin-fill reflections are also terminated near the eastern end of the transect, at about km 4 (Fig. 6). We think that the basin fill on these two transects is cut by the same fault system because the inferred basin-bounding fault lies in approximately the same position on a gravity gradient of $15-20 \mathrm{mGal}$ between the two transects (Fig. 3). Shallow, west-dipping reflections between $\mathrm{km} 5$ and $\mathrm{km} 6.5$ (horizontal distance) on line LV-1aext could be Tertiary sedimentary deposits (or Paleozoic rocks). The reflections appear to be offset by a small-displacement fault that projects upward to a mapped fault at $\mathrm{km} \sim 6$.

LV-3 trends subparallel to the California Wash valley axis and is situated entirely within the alluvial deposits. Basin-fill reflections along LV-3 thicken from south (base at about $1 \mathrm{~km}$ depth) to north (base at about $3 \mathrm{~km}$ depth; Fig. 7). A warping of the reflective package occurs at about $\mathrm{km} 10$ between 1 and $3 \mathrm{~km}$ depth. Gravity values are consistent with thickening of the basin fill to $\mathrm{km} 10$. Only one gravity station controls the abrupt increase in gravity values north of $\mathrm{km} \mathrm{10,} \mathrm{which} \mathrm{is} \mathrm{not} \mathrm{mirrored} \mathrm{by} \mathrm{an} \mathrm{abrupt}$ decrease in basin thickness in the seismic-reflection data. The strong reflection at the base of the reflective package between $\mathrm{km} 10$ and $\mathrm{km} 13$ at approximately $3 \mathrm{~km}$ depth is most likely the base of the Tertiary sedimentary fill; alternatively, it could be a faultplane reflection of the basin-bounding fault to the east.

\section{DEPTH TO BASEMENT}

We calculated the depth to basement, defined to be pre-Cenozoic rocks, beneath the area of California Wash to define the shape of the underlying basins and to determine the geometry of bounding and internal faults.

\section{Method}

The method used in this study to estimate the thickness of Cenozoic rocks is an updated version of the iterative method developed by Jachens and Moring (1990) that can 
incorporate drill hole and other geophysical data (Bruce Chuchel, U.S. Geological Survey, written commun., 1996; Fig. 8). The method requires knowledge of the residual gravity field, exposed geology, and vertical density variation within the Cenozoic basin deposits. Data from drill holes that penetrate bedrock and geophysical data can provide constraints on the thickness of the basin fill and are also input into the model to provide useful constraints to the inversion. The method separates the gravity field into two components, that which is caused by variations of density within the pre-Cenozoic basement rocks and that which is caused by variations of thickness of the Cenozoic basin fill. To accomplish this process, the gravity data are separated into observations made on pre-Cenozoic outcrops and those made on basin fill. The inversion is complicated by two factors: (1) gravity stations measured on pre-Cenozoic rock are influenced by the gravity anomaly caused by low-density deposits in nearby basins, and (2) the basement gravity field varies laterally because of density variations within the pre-Cenozoic basement. The inversion presented here does not take into account lateral variations in the density distribution of the Cenozoic deposits. Lateral variations in basin fill density can be large, in extreme cases inferred to be as high as $0.30 \mathrm{~g} / \mathrm{cm}^{3}$ from seismic velocities measured in the Mobil Virgin River 1A well (Bohannon and others, 1993). However, we think that most density variations would not change the overall general shape of the basin as predicted by the method unless the variations were abrupt.

To overcome these difficulties, a first approximation of the basement gravity field is determined by interpolating a smooth surface through all gravity values measured on bedrock outcrops. Basement gravity values are also calculated at locations where drill holes penetrated bedrock or seismic-reflection data constrain the basement surface, using the Cenozoic density-depth function (table 2). The basin gravity is then the difference between the observed gravity field on the original map and the first approximation of the basement gravity field and is used to calculate the first approximation of the thickness of Cenozoic deposits. The thickness is forced to zero where pre-Cenozoic basement is exposed. This first approximation of the bedrock gravity is too low near the basin edges because of the effects of the nearby low-density deposits on the basement stations. The basement gravity station values are "corrected" for the effects of the low-density deposits (the effects are calculated directly from the first approximation of the thickness of the 
Cenozoic deposits) and a second approximation of the basement gravity field is made by interpolating a smooth surface through the corrected basement gravity observations. This iteration leads to an improved estimate of the basin gravity field, an improved depth to bedrock and a new correction to the basement gravity values. This procedure is repeated until successive iterations produce no significant changes in the basement gravity field.

\section{Table 3. Density-depth functions for Cenozoic sedimentary deposits*}

\begin{tabular}{|c|c|c|c|}
\hline Depth & Model A & Depth & Iodel B \\
\hline Range & (Based on Virgin well) & Range & (Based on LV-1) \\
\hline $0-500 \mathrm{~m}$ & -0.56 & $0-600 \mathrm{~m}$ & -0.57 \\
\hline $500-1200 \mathrm{~m}$ & -0.52 & $600-1200 \mathrm{~m}$ & -0.31 \\
\hline $1200-2100 \mathrm{~m}$ & -0.33 & $1200-1800 \mathrm{~m}$ & -0.19 \\
\hline$>2100 \mathrm{~m}$ & -0.20 & $>1800 \mathrm{~m}$ & -0.09 \\
\hline
\end{tabular}

*density contrast in $\mathrm{g} / \mathrm{cm}^{3}$.

\section{Results}

We created two basin models (fig. 9). Both models utilize basement gravity stations and well and seismic constraints. The first model (A) uses the density-depth function derived from sonic velocities shown in Bohannon and others (1993); the second (B), using densities derived from our analysis of interval velocities along LV-1 (Table 2). In addition to the seismic picks from the three profiles presented in this report, we also used picks on basement from seismic lines outside of California Wash described in Carpenter and Carpenter (1994).

The resulting basin models, regardless of the density-depth function utilized, are similar, except in the magnitude of thickness (fig. 9). Model A predicts a maximum basin thickness of $2.8 \mathrm{~km}$ along the eastern part of the basin underlying California Wash whereas Model B predicts $3.3 \mathrm{~km}$. Both models indicate that the eastern margin of the basin is deeper than the western margin. The eastern margin of the basin is displaced 2-3 $\mathrm{km}$ west of mapped faults (Dohrenwend and others, 1996) offsetting the basin fill. These results are consistent with seismic profiles LV-1 and LV-1aext that support a more westerly position of the main basin edge. This basin margin fault, marked by the steep gravity gradient and abrupt termination of basin fill reflections along LV-1 and LV-1aext, 
is assumed to be part of the California Wash fault zone. The western margin of this basin is less pronounced according to both the gravity and seismic data. Basin fill is thinner (< $1 \mathrm{~km}$ ) beneath Dry Lake Valley to the west. Neither the gravity nor the seismicreflection data indicate major basin-bounding faults in Dry Lake Valley. The gentlydipping eastern edge of the basin is $\sim 250 \mathrm{~m}$ west of mapped young faults along the eastern margin of Dry Lake Valley (Fig. 2). We find no evidence that these mapped

young faults have dip-slip displacements of $>100 \mathrm{~m}$. If the eastern margin is structurally controlled, the margin consists of several, small-displacement normal (or strike-slip) faults with a cumulative offset of less than $1 \mathrm{~km}$.

\section{DISCUSSION AND RECOMMENDATIONS}

Figure 10 shows the interpretation of seismic-reflection profile, LV-1, with constraints from modeling of the gravity and magnetic data. Based on the seismic data, we define two Cenozoic sedimentary packages based on an unconformity in the California Wash basin between $\mathrm{km} 12$ and 20 at $0.5 \mathrm{~km}$ depth. We interpret that the upper package consists of relatively undeformed Muddy Creek Formation and that the lower package is Horse Spring Formation based on more extensive seismic information and a deep drill hole (Mobil Virgin River 1A well on Fig. 1) in the Virgin River Valley area. Most likely the lower package consists of the Bitter Ridge limestone member of the Horse Spring Formation, which is exposed at the south end of California Wash valley (Bohannon, 1984). Similar unconformities occur on both LV-1aext (at km 0 and $1.4 \mathrm{~km}$ depth) and LV-3 (see km 10 at a depth of $1 \mathrm{~km}$ ). Below the sedimentary fill of Dry Lake Valley, the Dry Lake thrust separates west-dipping relatively coherent reflections of the upper plate from disrupted reflections in the lower plate at $\mathrm{km} 6$ and $0.5 \mathrm{~km}$ depth.

Upper-plate rocks at the base of the thrust are most likely the Cambrian Nopah Formation which occurs in surface exposures of the thrust $~ 14$ km south of LV-1 near Apex and 12 km north of LV-1 in the Arrow Canyon Range (Page, 1992; Page and Dixon, 1992). Along LV-1, the Dry Lake thrust projects eastward above the Dry Lake Range, and lower-plate rocks of the Bird Spring Formation are exposed at the surface between $\mathrm{km} 8$ and 9. The lower-plate rocks become steeply overturned on the western flank of the 
exposures near LV-1, beneath the projected trace of the thrust fault (Longwell and others, 1965).

Based on modeling of the magnetic data, we suggest that the strong reflections at 4-5 km depth between $\mathrm{km} 7$ and 10 are the top of magnetic Precambrian crystalline basement. Another Precambrian high based on magnetic data at the eastern end of the profile is inferred, although its geometry is not constrained by the seismic-reflection data. Its western edge is roughly coincident with a change in the predominant dip of the reflections between $2-8 \mathrm{~km}$ depth, with predominantly west-dipping reflections east of $\mathrm{km} 20$ and predominantly east-dipping reflections west of $\mathrm{km} 19$. One possible interpretation of the change in dip is a concave-downward fault that offsets Precambrian magnetic basement, perhaps similar to the geometry proposed for north-northeaststriking, oblique-slip faults in the Candy Peak area in the extreme northeast corner of the study area (Anderson and Barnhard, 1993).

The accuracy of the basin models depends on how well constrained various input parameters are. The inversion uses geology compiled at a scale of 1:1,000,000 (Stewart and Carlson, 1978). More precise knowledge of the basement lithologies and contacts would improve the model. Larger uncertainties, though, arise from the distribution of gravity data and poor constraints on the density-depth function.

The basin models suffer from sparse gravity data, particularly for the area north of $36^{0} 30^{\prime}$. Thus, the details of the basin shape and location must be viewed with caution, especially in those areas without seismic-reflection or gravity data. For instance, the eastern third of the gravity profile along LV-3 is constrained by a single gravity station in the basin and probably accounts for the apparent discrepancy between the seismicreflection and gravity data. More gravity data in this area could help resolve whether the deep reflection at $3 \mathrm{~km}$ depth is the base of the sedimentary fill or a fault-plane reflection. Gravity data in the basins are needed for a better gravity inversion. Detailed, highresolution gravity profiles along the margins of the basins would locate strands of faults (see Phelps and others (2000) for an example from Coyote Springs Valley or Langenheim and others (1998) for an example from Las Vegas Valley). Basement gravity stations are particularly needed in the northwestern Muddy Mountains and the Arrow Canyon Range to help control the inversion in the northern part of the study area. 
Additional drill-hole data and a better density-depth function would allow us to greatly refine the current models of the basins. Because our models are constrained only by basement gravity stations and spatially limited well and seismic data, the basement gravity field cannot resolve basement gravity anomalies that have wavelengths less than the spacing between basement outcrops with gravity observations and wells and seismic control points (as much as $10 \mathrm{~km}$ across in some areas). In these areas, the basin model may not be accurate. Drill-hole data, particularly those wells that provide depths to basement rocks, could greatly improve the resolution of the basement gravity field. Additional geophysical data, such as electrical data, would also provide much needed, independent constraints on basin thickness. Additional seismic-reflection data would not only improve the basin thickness model, but also image the geometry of basin-bounding and thrust faults that are important inputs to a hydrogeologic framework. The densitydepth function based on interval velocities could be improved by borehole gravity surveys or by seismic-refraction data.

Higher-resolution aeromagnetic data could highlight intrabasinal faults. Highresolution aeromagnetic data covering the area of Albuquerque, New Mexico, were successful in mapping faults within the basin fill (Grauch and others, 2001). A highresolution aeromagnetic survey in the Virgin Valley area, Nevada-Arizona-Utah imaged not only faults within the Tertiary deposits, but also paleochannels (Jachens and others, 1998). High-resolution aeromagnetic data could also resolve the magnitude of strike-slip movement on faults bounding the eastern margin of California Wash basin.

\section{REFERENCES}

Anderson, R.E., and Barnhardt, 1993, Aspects of three-dimensional strain at the margin of the extensional orogen, Virgin River depression area, Nevada, Utah and Arizona: Geological Society of America Bulletin, v. 105, p. 1019-1052.

Bohannon, R.G., 1983, Mesozoic and Cenozoic tectonic development of the Muddy, North Muddy, and northern Black Mountains, Clark county, Nevada in Miller, D.M., Todd, V.R., and Howard, K.A., eds., Tectonic and Stratigraphic Studies in the Eastern Great Basin: Geological Society of America Memoir 157, p. 125-148.

Bohannon, R.G., 1984, Nonmarine sedimentary rocks of Tertiary age in the Lake Mead region, southeastern Nevada and northwestern Arizona: U.S. Geological Survey Professional Paper 1259, 72 p.

Bohannon, R.G., Grow, J.A., Miller, J., and Blank, H.R., Jr., 1993, Seismic stratigraphy and tectonic development of Virgin River depression and associated basins, 
southeastern Nevada and northwestern Arizona: Geological Society of America Bulletin v. 105, p. 501-520.

Carpenter, J.A., and Carpenter, D.G., 1994, Analysis of Basin-Range fold-thrust structure, and reinterpretation of the Mormon Peak detachment and similar features as gravity-slide systems; southern Nevada, southwest Utah, and northwest Arizona, in Dobbs, S.W., and Taylor, W.J., eds., Structural and Stratigraphic Investigations and Petroleum Potential of Nevada, with special emphasis south of the Railroad Valley Producing Trend; Nevada Petroleum Society Conference Volume I, p. 15-52.

Carpenter, J.A., and Carpenter, D.G., 1994, Fold-thrust structure, synorogenic rocks, and structural analysis of the north Muddy Mountains and Muddy Mountains, Clark County, Nevada, in Dobbs, S.W., and Taylor, W.J., eds., Structural and Stratigraphic Investigations and Petroleum Potential of Nevada, with special emphasis south of the Railroad Valley Producing Trend; Nevada Petroleum Society Conference Volume I, p. 65-94.

Dettinger, M.D., Harrill, J.R., and Schmidt, D.L., 1995, Distribution of carbonate-rock aquifers and the potential for their development, southern Nevada and adjacent parts of California, Arizona, and Utah: U.S. Geological Survey Water Resources Investigations Report 91-4146, 100 p.

Dohrenwend, J.C., Schell, B.A., Menges, C.M., Moring, B.C., and McKittrick, M.A., 1996, Reconnaissance photogeologic map of young (Quaternary and late Tertiary) faults in Nevada: Nevada Bureau of Mines and Geology Open-File Report 96-2.

Gardner, G.H., Gardner, L.W., and Gregory, A.R., 1974, Formation velocity and density: the diagnostic basis for stratigraphic traps: Geophysics, v. 39, p. 770-780.

Grauch, V.S., Hudson, M.R., and Minor, S.A., 2001, Aeromagnetic expression of faults that offset basin fill, Albuquerque basin, New Mexico: Geophysics, v. 66, p. 707720.

International Union of Geodesy and Geophysics, 1971, Geodetic reference system 1967: International Association of Geodesy Special Publication no. 3, 116 p.

Jachens, R.C., and Moring, B.C., 1990, Maps of the thickness of Cenozoic deposits and the isostatic residual gravity over basement for Nevada: U.S. Geological Survey Open-File Report 90-404, 15 p., 2 plates, scale 1:1,000,000.

Jachens, R.C., Dixon, G.L., Langenheim, V.E., and Morin, R., 1998, Interpretation of an aeromagnetic survey over part of Virgin Valley, Tule Desert, and the valley surrounding Meadow Valley wash, southeastern Nevada: U.S. Geological Survey Open-File Report 98-804 16 p.

Kane, M.F., Healey, D.L., Peterson, D.L., Kaufmann, H.E., and Reidy, D., 1979, Bouguer gravity map of Nevada_Las Vegas sheet: Nevada Bureau of Mines and Geology Map 61, scale 1:250,000.

Langenheim V.E., Davidson, J.G., Anderson, M.L., and Blank, H.R., Jr., 1999, Principal facts for gravity stations and physical property measurements in the Lake Mead 30' by 60' quadrangle, Nevada and Arizona: U.S. Geological Survey Open-File Report 99-435, (http://pubs.usgs.gov/of/1999/of99-435/).

Langenheim, V.E., Grow, J., Miller, J., Davidson, J.G., and Robison, E., 1998, Thickness of Cenozoic deposits and location and geometry of the Las Vegas Valley shear 
zone, Nevada, based on gravity, seismic-reflection, and aeromagnetic data: U.S. Geological Survey Open-File Report 98-576, 31 p.

Longwell, C.R., Pampeyan, E.H., Bowyer, Ben, and Roberts, R.J., 1965, Geology and mineral deposits of Clark County, Nevada: Nevada Bureau of Mines and Geology Bulletin 62, 218 p.

Morelli, Carlo, 1974, The International Gravity Standardization Net, 1971: International Association of Geodesy Special Publication no. 4, 194 p.

Page, W.R., 1992, Preliminary geologic map of the Paleozoic rocks in the Arrow Canyon quadrangle, Clark County, Nevada: U.S. Geological Survey Open-File Report 92-681, 1:24,000-scale.

Page, W.R., and Dixon, G.L., 1992, Northern terminus of the Mesozoic Dry Lake thrust fault, Arrow Canyon Range, southeastern Nevada [abs.]: Geological Society of America Abstracts with Programs, v. 24, no. 6, p. 56.

Phelps, G.A., Jewel, E.B., Langenheim, V.E., and Jachens, R.C., 2000, Principal facts for gravity stations in the vicinity of Coyote Spring valley, Nevada, with initial gravity modeling results: U.S. Geological Survey Open-File Report 00-420 (http://pubs.usgs.gov/of/2000/of00-420/).

Rush, F.E., 1968, Water-resources appraisal of the Lower Moapa-Lake Mead area, Clark County, Nevada: Department of Conservation and Natural Resources, Water Resources-Reconnaissance Series, no.50, 66 pp.

Saltus, R.W., and Ponce, D.A., 1988, Aeromagnetic map of Nevada-Las Vegas sheet: Nevada Bureau of Mines and Geology Map 95, scale 1:250,000.

Simpson, R.W., Jachens, R.C., Blakely, R.J., and Saltus, R.W., 1986, A new isostatic gravity map of the conterminous United States with a discussion on the significance of isostatic residual anomalies: Journal of Geophysical Research, v. 91, p. 8348-8372.

Stewart, J.H., and Carlson, J.E., 1977, Million-scale geologic map of Nevada: Nevada Bureau of Mines and Geology Map 57, scale 1:1,000,000.

Tschanz, C.M., and Pampeyan, E.H., 1970, Geology and Mineral Deposits of Lincoln County, Nevada: Nevada Bureau of Mines and Geology Bulletin 73, $188 \mathrm{p}$

Winograd, I.J., and Thordarson, W., 1975, Hydrogeologic and hydrochemical framework, south-central Great Basin, Nevada-California, with special reference to the Nevada Test Site: U.S. Geological Survey Professional Paper 712-C, 126 p. 


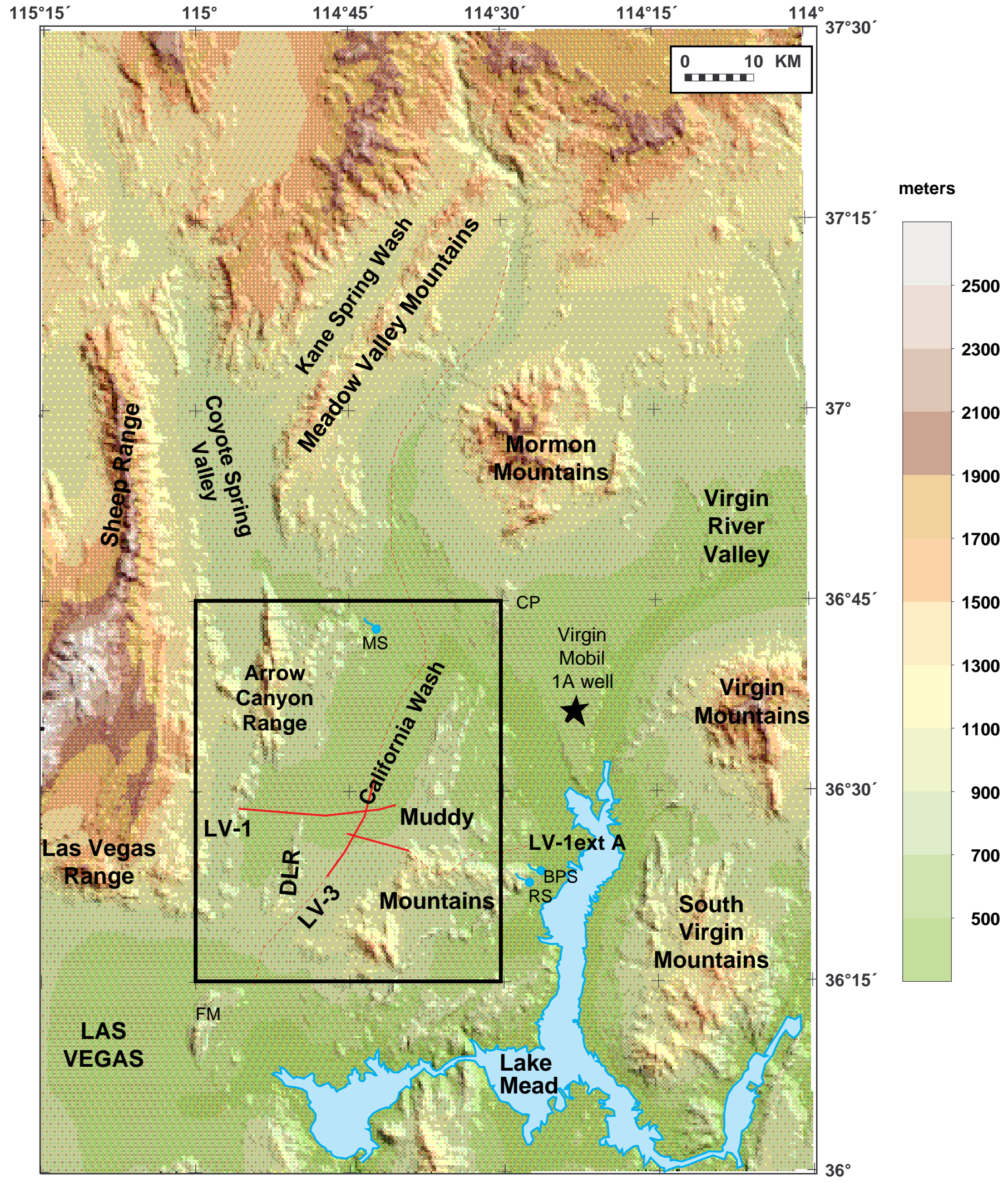

Figure 1. Topographic map of study area (outlined by box) and vicinity. Red lines are the three seismic profiles discussed in this report. Dashed red lines are parts of the seismic profiles that remain strictly proprietary. BPS, Blue Point Spring; CP, Candy Peak; DLR, Dry Lake Range; FM, Frenchman Mountain; MS, Muddy Springs; RS, Rogers Spring. 


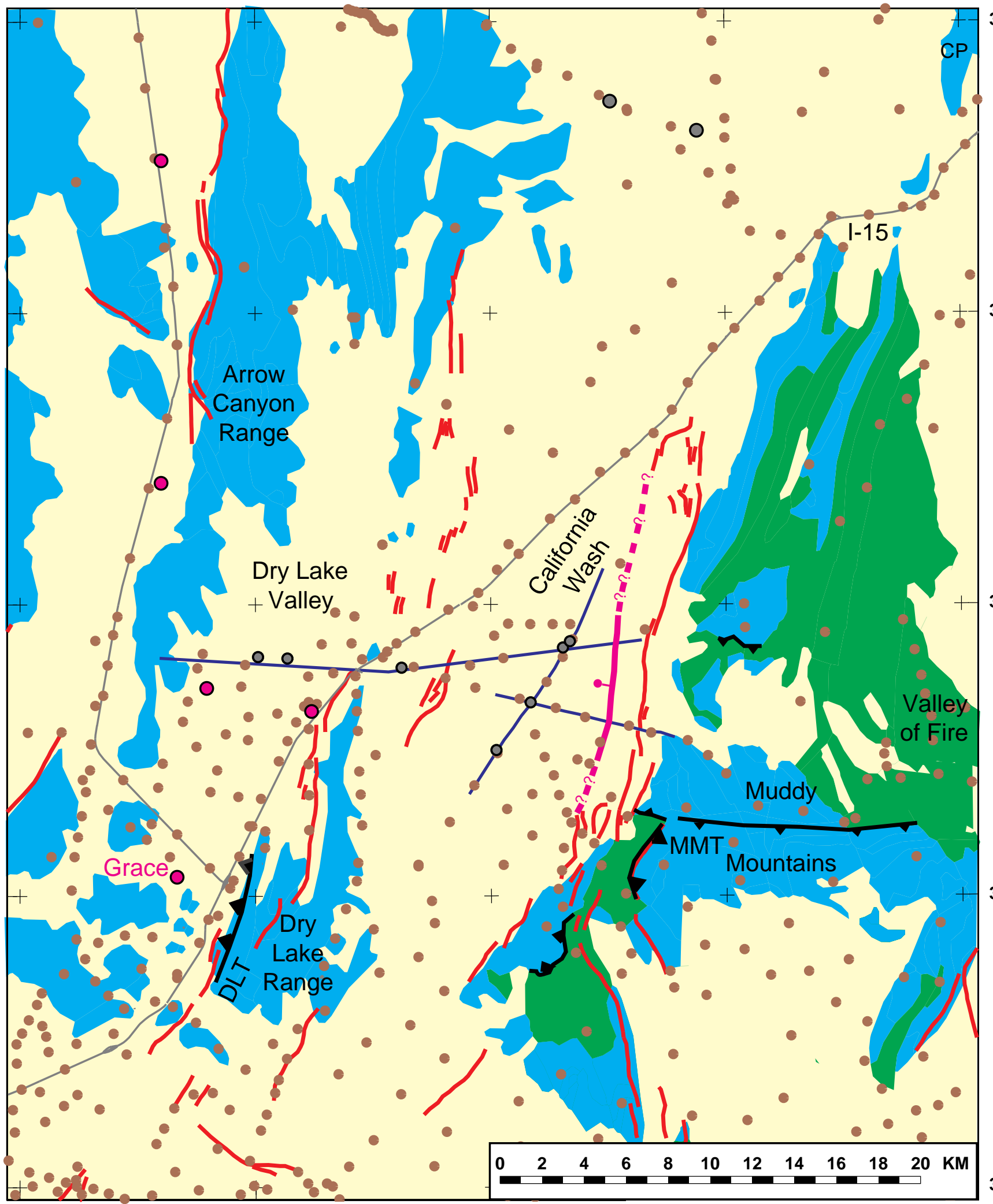

Figure 2. Geologic map of study area. Blue, Paleozoic rocks; green, Mesozoic rocks; yellow, Cenozoic rocks. Brown dots, gravity stations, red lines, faults from Dohrenwend and others (1996). Dark blue lines, seismic-reflection profiles from this study. Thick black lines are thrust faults with barbs on upper plate. Magenta circles, wells; gray circles, picks on basement from seismicreflection data (Carpenter and Carpenter, 1994; this study). Thick magenta lines, interpreted basin-bounding fault from gravity and seismic data. CP, Candy Peak; DLT, Dry Lake thrust fault; MMT, Muddy Mountain thrust fault. 


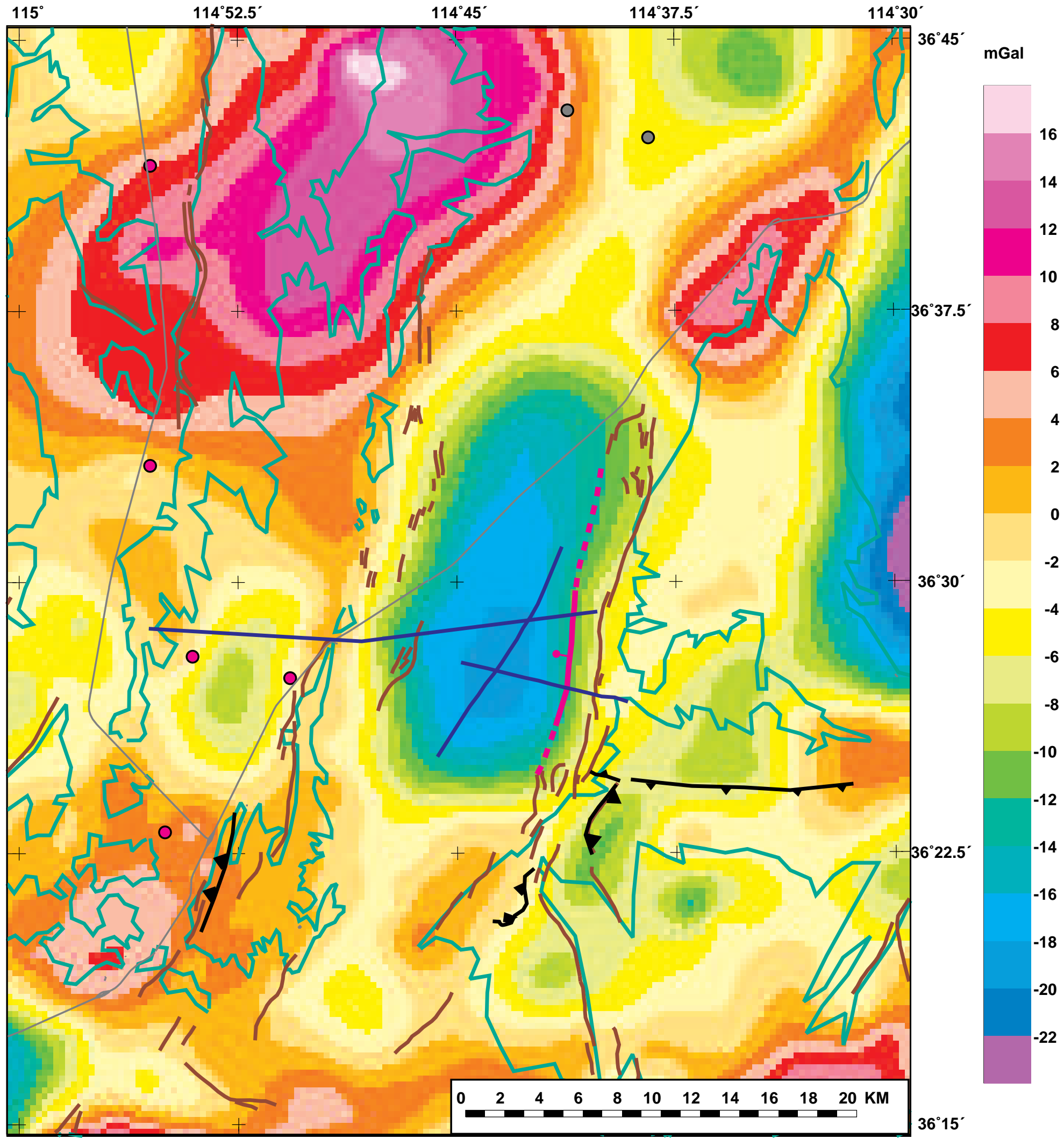

Figure 3. Isostatic gravity map of study area. Green lines are extent of pre-Cenozoic rocks. Brown lines, late Tertiary and Quaternary faults from Dohrenwend and others (1996). See Figure 2 for explanation of other symbols. 


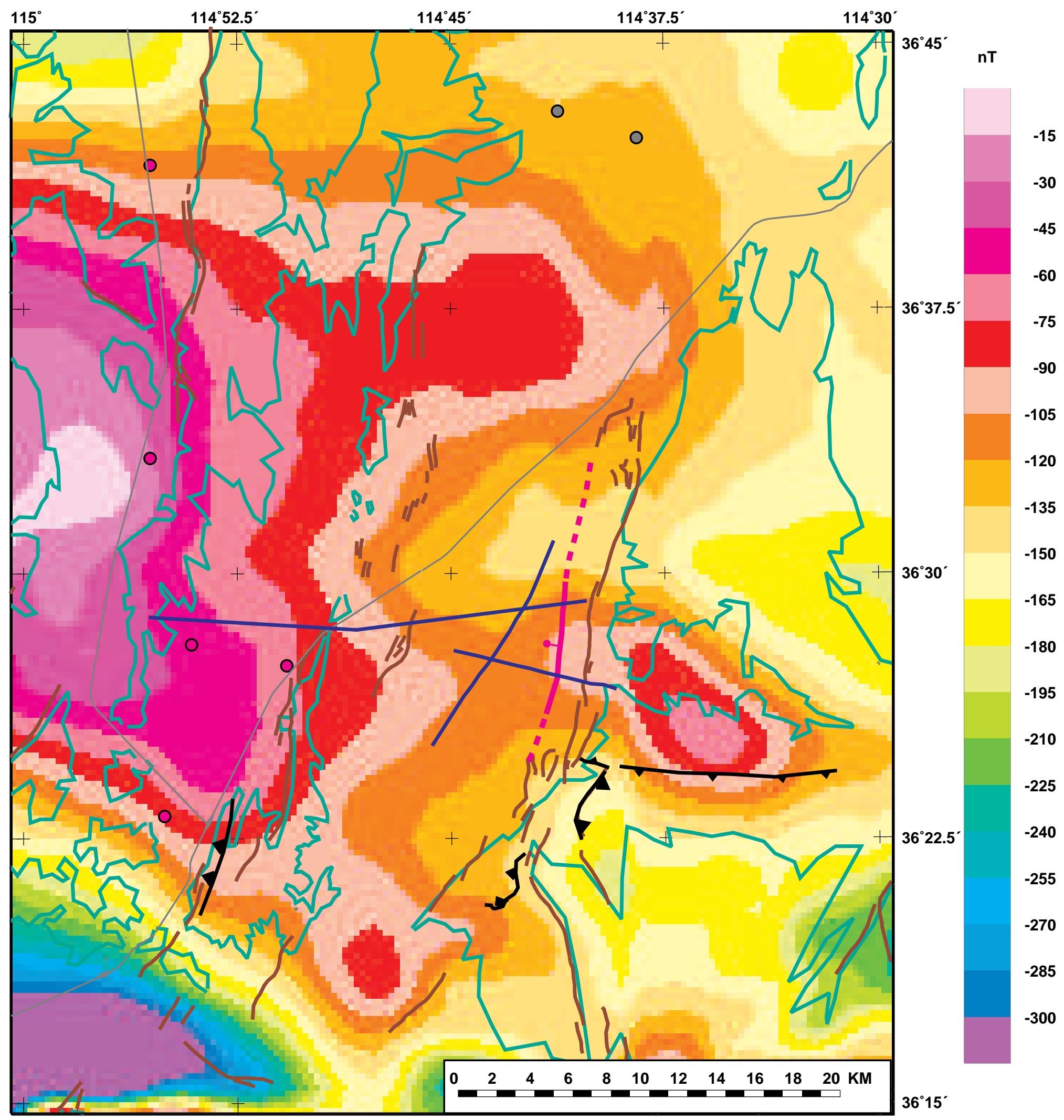

Figure 4. Aeromagnetic map of study area. Green lines are extent of pre-Cenozoic rocks. See Figures 2 and 3 for explanation of symbols. 

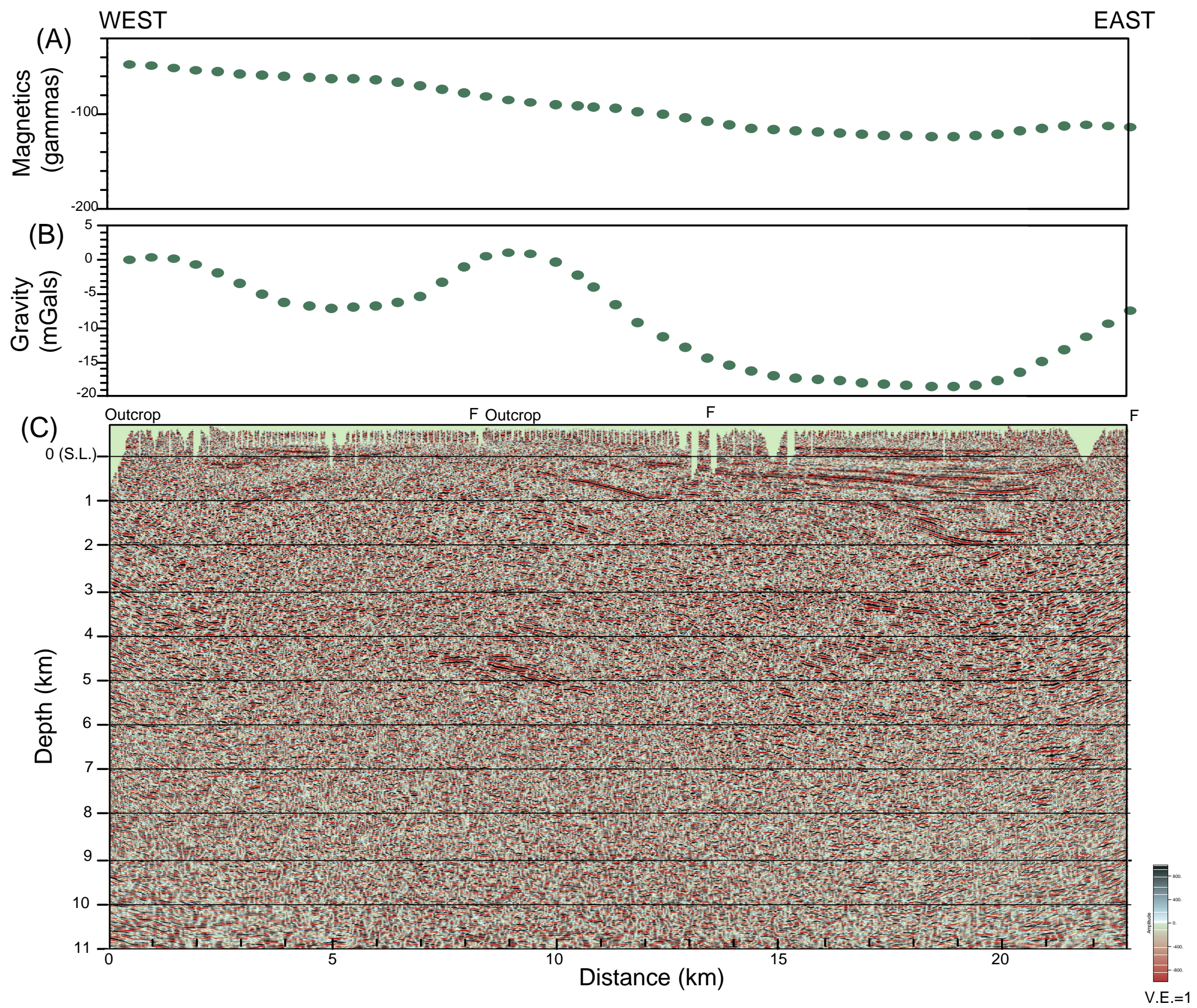

Figure 5. Geophysical data along profile LV-1. (A) Gridded aeromagnetic data (B) Gridded isostatic gravity. (C) Depth section of seismic-reflection data. Outcrop, exposure of pre-Cenozoic rock; $\mathrm{F}$, fault from Dohrenwend and others (1996). See Figure 10 for interpretation. 

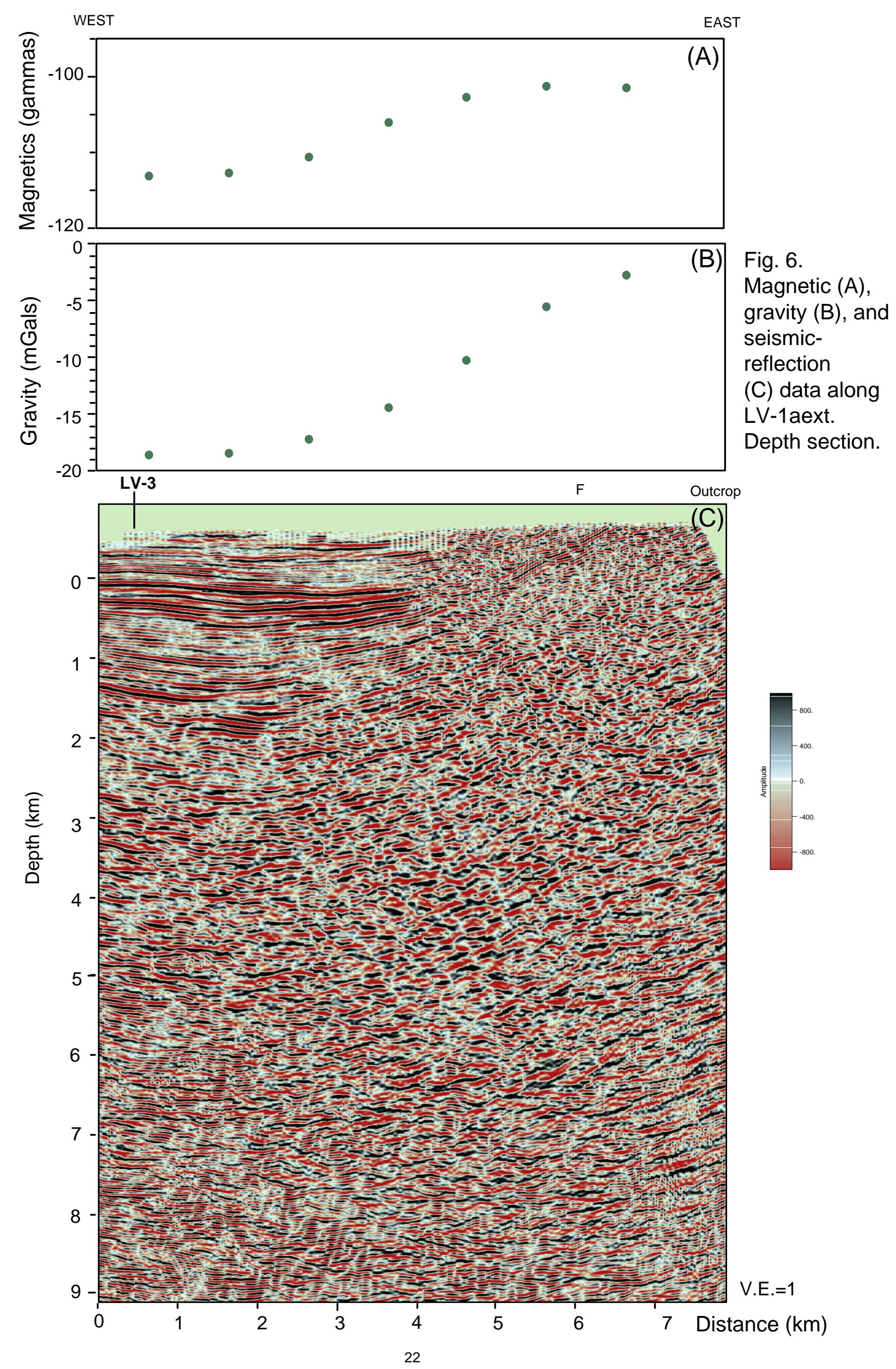

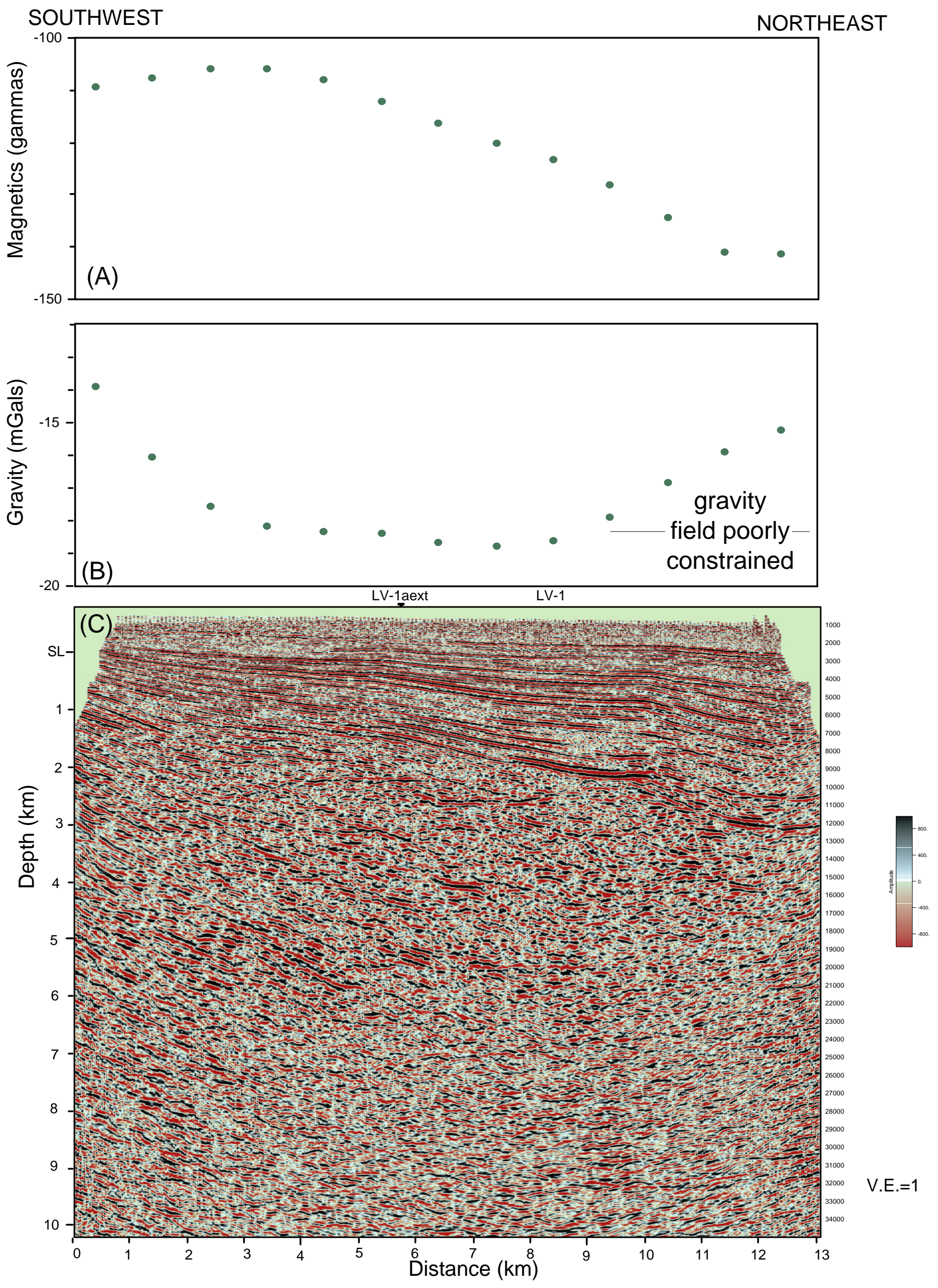

Figure 7. Gridded magnetic (A), gridded gravity (B), and seismic-reflection (C) data along LV-3. Depth section. 


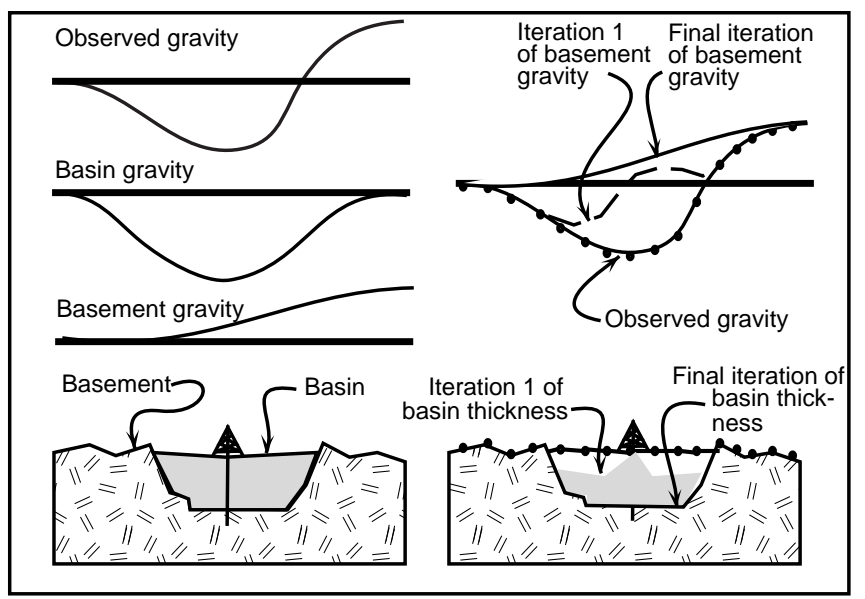

Figure 8. Schematic representation of the gravity separation procedure. 


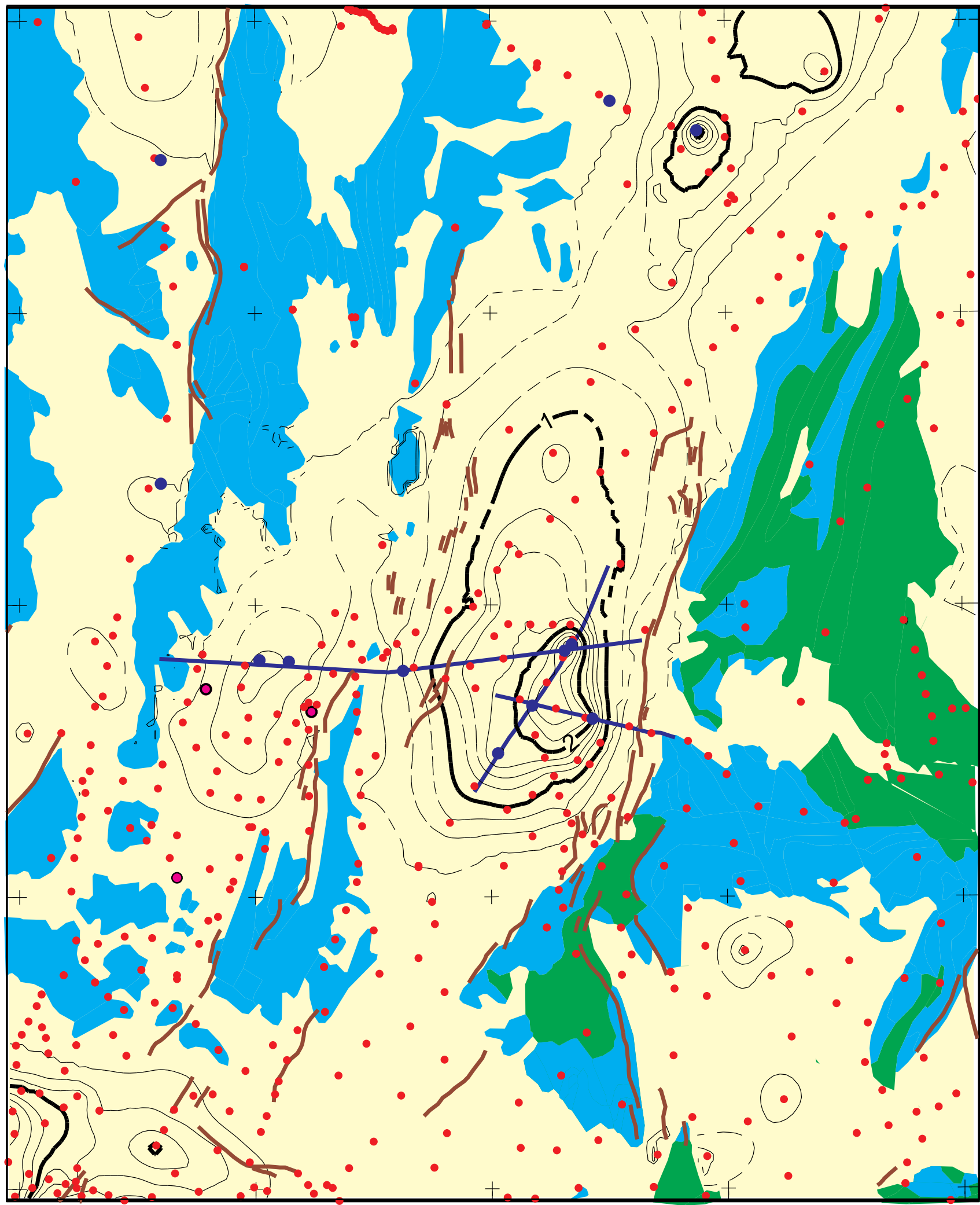

$$
\begin{array}{llllllllllll}
0 & 2 & 4 & 6 & 8 & 10 & 12 & 14 & 16 & 18 & 20 & \mathrm{KM}
\end{array}
$$

Figure 9A. Basin thickness using density-depth function derived from sonic log of the Mobil Virgin 1A well. Contour intervals, $250 \mathrm{~m}, 1 \mathrm{~km}$. Red dots, gravity stations, magenta circles, wells; purple circles, seismic picks on basement. 


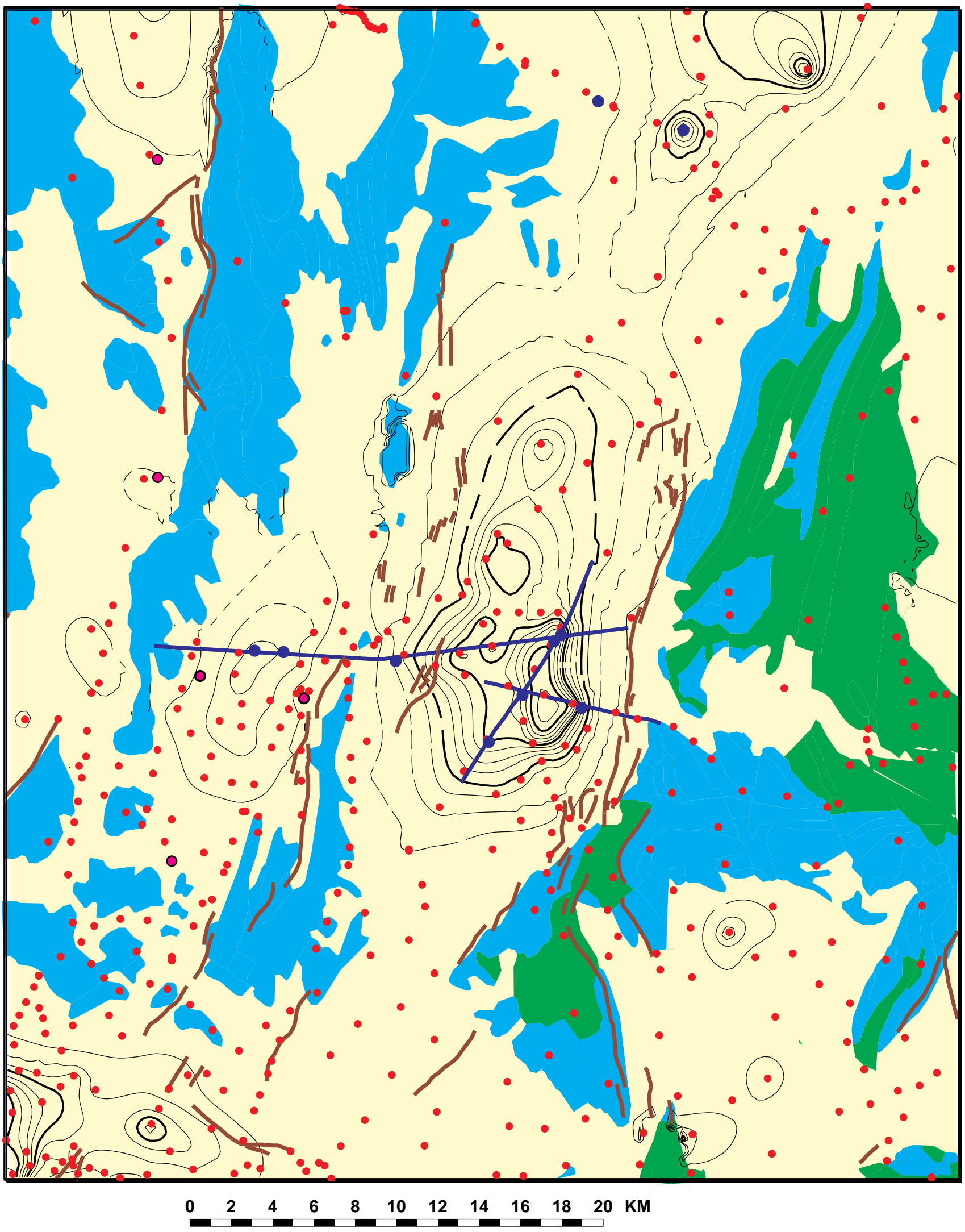

Figure 9B. Basin thickness using density-depth function derived from interval velocities from LV-1. Contour intervals, $250 \mathrm{~m}, 1 \mathrm{~km}$. Red dots, gravity stations, magenta circles, wells; purple circles, seismic picks on basement. 

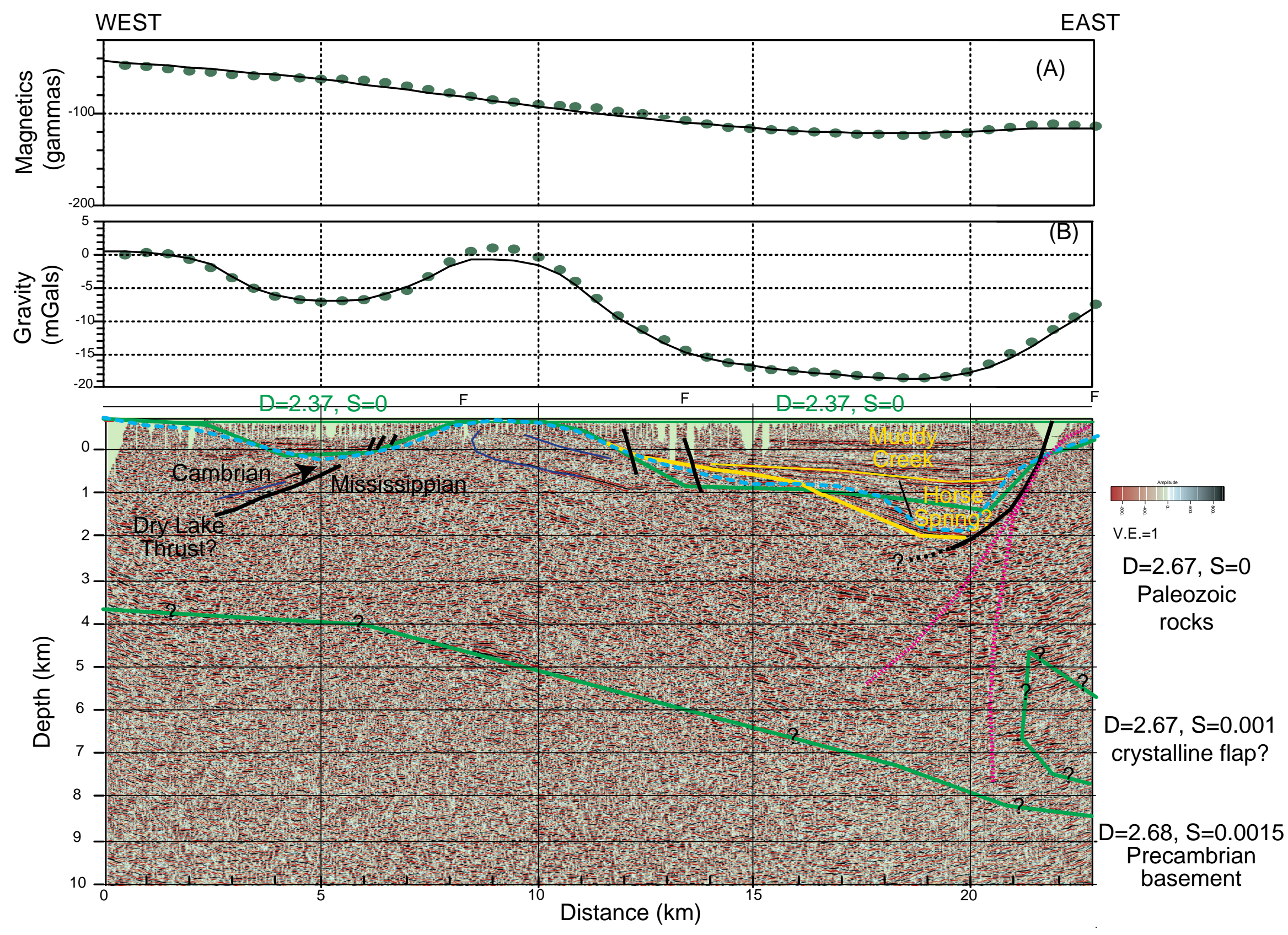

Figure 10. Interpretation of LV-1. (A) Gridded aeromagnetic data (B) Gridded isostatic gravity. (C) Depth section of seismic-reflection data. Green lines on depth section are outlines of density ( $D$ in $\left.\mathrm{g} / \mathrm{cm}^{3}\right)$ and magnetic $\left(S\right.$ in $10^{-3} \mathrm{cgs}$ units) bodies used to calculate curves shown in (A) and (B). Yellow lines outline sedimentary packages interpreted from seismic data. Black lines are interpreted faults from the seismic-reflection data. Dotted magenta lines are alternate fault locations for the faults bounding the eastern margin of California Wash valley. Dotted blue line is basin depth from Model A. Dark blue lines mark bedding in pre-Cenozoic rocks. 